УДК $616.31+378.14$

\title{
СУЧАСНІ ПІДХОДИ ДО ЗАБЕЗПЕЧЕННЯ ЯКІСНОЇ ОСВІТИ ЛІКАРІВ-СТОМАТОЛОГІВ
}

\author{
В. М. Ждан, В. М. Бобирьов, О. В. Шешукова, С. М. Білаш, Н. М. Лохматова, \\ Т. В. Шарбенко
}

Вищий державний навчальний заклад Украйни

“Українська медична стоматологічна академія”, м. Полтава

\section{MODERN APPROACHES FOR ENSURING OF QUALITATIVE EDUCATION OF DOCTORS-STOMATOLOGISTS}

\author{
V. M.Zhdan, V. M. Bobyrov, O. V. Sheshukova, S. M. Bilash, N. M. Lohmatova, \\ T. V. Sharbenko \\ Higher State Educational Institution of Ukraine \\ "Ukrainian Medical Stomatological Academy”, Poltava
}

\begin{abstract}
Розвиток технічного процесу та запровадження новітніх технологій, сучасні досягнення науки і технічні умови дозволяють визначити нові підходи до забезпечення якісної освіти лікарів-стоматологів, які нададуть можливість отримати конкурентоспроможних висококваліфікованих фахівців.
\end{abstract}

The development of technical progress and introducing of modern technologies, current achievements of science and technical conditions enable to determine new approaches for ensuring qualitative education of doctors-stomatologists, which let the possibility to train competitive and highly qualified specialists.

Вступ. Входження України до єдиного Європейського простору вимагає підвищення якості професійної підготовки майбутніх лікарів відповідно до світових стандартів 3 метою посилення конкурентоспроможності вітчизняної вищої медичної освіти, оптимізації умов для міжнародної мобільності і розширення можливостей українських медичних фахівців на вітчизняному і міжнародному ринках праці. Тому провідною метою діяльності вищого навчального закладу є навчання і підготовка випускника, який у результаті отримання ступеневої вищої освіти опановує сучасними технологіями пошуку й обробки інформації та зможе використовувати засвоєні знання в практичній діяльності лікаря.

Основна частина. Приєднання до Болонської декларації, впровадження європейських стандартів освіти шляхом перебудови процесу навчання потребують від колективу академії комплексної діяльності щодо створення, освоєння, використання й поширення новітніх педагогічних технологій. Організація навчального процесу в сучасних умовах вимагає поєднання різних технологій та творчого підходу до використання кожної з них, а також створення нових $[1,2]$.
Широке застосування інновацій (програмоване навчання, експертні системи, мультимедіа, імітаційне моделювання, предметні комп'ютерні практичні заняття) сприяє підвищенню пізнавального інтересу, творчої активності студентів, відкриває нові можливості для самонавчання, розширення світогляду, збагачує студентів і викладачів знаннями в опануванні новими методами діагностики та лікування.

Неоціненну допомогу в опануванні практичними навичками та вміннями, засвоєнні знань надають технічні засоби навчання. Навчальні кімнати багатьох теоретичних кафедр обладнані комп'ютерами та мультимедійними проекторами, що дає можливість у повному обсязі подати матеріал з тієї чи іншої теми практичного заняття. Так, наприклад, студенти на кафедрах морфологічного профілю опановують матеріал не тільки теоретично, а й вивчають гістологічні мікропрепарати за допомогою світлового та цифрового мікроскопів із застосуванням інформаційних комп’ютерних програм, практикумів, спрямованих на ефективне засвоєння і закріплення знань. Комп'ютери кафедр об'єднані у внутрішню мережу та мають доступ до Internet, що дає можливість постійно по-

() В. М. Ждан, В. М. Бобирьов, О. В. Шешукова та ін. 
новлювати матеріал із дисциплін, доповнювати даними нових наукових досліджень вітчизняних і закордонних учених. Студенти мають можливість переглядати взяті з мережі Internet гістологічні мікропрепарати та науково-практичні кінофільми відповідно до теми практичного заняття, брати дистанційну участь у наукових конференціях.

У світлі гуманізації освіти особливо доцільно використовуватипри вивченні нормальної фізіології, патологічної фізіології, оперативної хірургії та топографічної анатомії розроблені пакети комп'ютерних (аудіовізуальних) програм дослідів, які демонструють програмне моделювання оперативних втручань та передбачають не тільки навчання, а й контроль знань. Студенти за цими програмами мають можливість проводити оперативні втручання за допомогою комп'ютера згідно із заданими умовами, визначати найбільш доцільні дії та виявляти помилки і можливі ускладнення. Це дає можливість майбутньому фахівцю розвинути своє клінічне мислення 3 подальшим проведенням повного аналізу завершальних результатів.

Формування професійних компетенцій під час навчання у вищому навчальному закладі реалізується за допомогою компетентнісного підходу до підготовки майбутніх фахівців [3]. Робота лікаря-стоматолога має свою специфіку: невеликої площі ділянка діяльності; використання складного технічного обладнання, яке потребує значних матеріальних витрат, високовартісних інструментарію та лікарських засобів; особливості морально-етичних взаємовідносин “лікар-пацієнт”. Тому академія проводить активну роботу щодо впровадження новітніх методів вивчення дисциплін: постійне матеріально-технічне вдосконалення оснащення кафедр; інтенсивна модернізація і технологізація навчального процесу та наукової роботи; створення на громадських засадах навчальнонауково-виробничих об'єднань, науково-практичних і навчально-практичних тренінгових центрів, навчально-практичних лабораторій. Ці заходи забезпечують студенту поглиблене вивчення предмета, сприяють систематизації отриманих знань, дозволяють розвинути творче мислення та удосконалити практичні навички в міждисциплінарних тренінгових класах на симуляторах (фантомах). Здобуті навички студенти застосовують у роботі з реальними пацієнтами вже на наступних етапах професійної практичної підготовки в клініці. Для цього був створений та активно функціонує навчально-науково-тренінговий “Стоматологічний центр”, де провідними фахівцями академії здійснюється навчально-методична робота й надається багатопрофільна консультативна та лікуваль- на стоматологічна допомога населенню міста та області.

Створення на клінічних кафедрах телекомунікаційних систем дає можливість великій кількості студентів спостерігати в реальному часі за виконанням стоматологічних маніпуляцій, оперативних втручань, технічних етапів виготовлення ортопедичних та ортодонтичних конструкцій. Це сприяє залученню всіх без винятку студентів групи в процес обговорення й обгрунтування власної думки, розвиває клінічне мислення і дає можливість запропонувати альтернативні ідеї та пропозиції (підходи), провести взаємонавчання і взаємовдосконалення. За застосування новітніх методів вивчення дисциплін (брейн-ринг, ділові ігри, тренінги, майстер-класи, методи конкурентних груп) активно реалізується творчий компонент навчання. Так, наприклад, науково-дослідна робота 3 використання комп'ютерних технологій в обгрунтуванні нових методів проведення реконструктивно-відновлювальних операцій у навчально-науковій лабораторії комп’ютерного планування і прогнозування пластичних операцій на кафедрі хірургічної стоматології та щелепно-лицевої хірургії з пластичною та реконструктивною хірургією голови та шиї дозволяє студентам реалізувати свій творчий потенціал, розширити рамки власної професійної компетентності, визначити напрям майбутньої професійної діяльності. Для цього на кафедрі створений комп'ютерний клас, оснащений стаціонарними комп’ютерами, ноутбуками, проекторами для читання лекцій та іншою сучасною технікою.

Майбутній лікар-стоматолог - перш за все лікар, i тому керівництво навчального закладу відповідально ставиться до підготовки висококваліфікованих спеціалістів. Теперішні студенти завтра будуть професіоналами системи охорони здоров'я, які зможуть на високому рівні надати всі види лікарської допомоги. Тому створення навчально-практичного тренінгового центру сучасних технологій перинатальної медицини було дуже своєчасним. Для виконання поставлених завдань у центрі було організовано такі структурні підрозділи: мультидисциплінарну клінічну лабораторію, яка складається 3 двох тренінгових кімнат - "Пологовий зал” i "Палата інтенсивної терапії новонароджених", віртуальну медичну лабораторію та телемедичну лабораторію.

Мультидисциплінарна лабораторія “Пологовий зал” призначена для відпрацювання клінічних, технічних і поведінкових навичок, при цьому вона може трансформуватися в різні клінічні підрозділи. Тренінгова кімната “Пологовий зал” обладнана пологовими симуляторами породіллі, що дають можливість імітувати процес 
фізіологічних іпатологічних пологів, ведення післяпологового періоду, моделювання невідкладних акушерських ситуацій, а також симулятором новонародженого, на якому можна відпрацьовувати екстремальні та рутинні клінічні ситуації. Під час навчання учасники тренінгу мають можливість ознайомитися з симуляторами, медичним обладнанням та іншими ресурсами, беруть участь у змодельованих рутинних клінічних ситуаціях та в складних екстрених ситуаціях із подалышим їх конструктивним розглядом. Віртуальна медична лабораторія, яка оснащена комп'ютерами і за необхідності може трансформуватися в лекційний зал, призначена для віртуального теоретичного навчання. Телемедична лабораторія, яка оснащена системою "Polycom QDX 6000” та плазмовою панеллю “LG 50"”, , призначена для проведення телемедичних видів навчання, конференцій, консультацій та клінічних розглядів ведення пацієнтів.

Упровадження в практичну діяльність лікаря новітніх технологій, використання сучасної апаратури дозволяють значно підвищити рівень підготовки лікаря-спеціаліста, що особливо актуально на післядипломному етапі навчання. Кафедри післядипломної освіти лікарів за стоматологічними фахами академії активно впроваджують та використовують сучасне забезпечення безперервної освіти, яка покликана допомогти медичним працівникам адаптуватися до змін, що відбуваються в медичній науці і практиці, усвідомлено ставитися до знань, уміти використовувати їх у різних практичної сферах охорони здоров'я. Безперервне навчання охоплює широку низку заходів - від підвищення професійної кваліфікації до спеціалізованих курсів.

За останні роки розвиток інформаційних технологій актуалізував проблему модернізації системи освіти, що найбільш втілилося в концепції дистанційної освіти, яка завдяки такому глобальному явищу, як Інтернет, охоплює широкі шари суспільства та стає найважливішим фактором його розвитку. Міжнародний досвід післядипломної професійної освіти лікарських кадрів свідчить про необхідність широкомасштабного впровадження передових освітніх технологій у традиційну систему [4]. Кафедра післядипломної освіти лікарів-стоматологів ВДНЗУ "УМСА" має у своєму складі дві філії в м. Чернігові і м. Кременчуці. Отже, впровадження в навчальний процес дистанційних технологій відіграє важливу роль та дає можливість безперервного розвитку, надання рівних прав у підвищенні професійної кваліфікації незалежно від місця проживання, динамічного процесу навчання і створення інформаційного потоку високої інтенсивності для значної кількості слухачів.
Дистанційна освіта іпідвищення кваліфікації лікарівстоматологів на кафедрах академії здійснюються такими шляхами:

- проведення дистанційних лекцій у рамках тематичних курсів, передатестаційних циклів або з актуальних питань стоматологіi;

- проведення семінарів із поглибленим вивченням раніше прочитаного лекційного матеріалу;

- практичні заняття з методів клініки, діагностики, диференційованої діагностики, лікування, а також індивідуальні телемедичні консультації;

- відеоконференції, майстер-класи.

Останнім часом у навчальний процес кафедри активно впроваджуються відеоконференції з міжнародною участю. У 2011-2012 н. р. кафедра організувала для лікарів-інтернів та курсантів он-лайн трансляції майстер-класів генерального директора “ARDSsystem Implants” (Ізраїль) Арні Урі - операції дентальної імплантації під час проведення навчальних семінарів “ARDS імпланти в практиці лікаря-стоматолога". За період партнерської співпраці кафедра післядипломної освіти лікарів-ортодонтів (зав. каф., проф. В. Д. Куроєдова) і ортодонтична клініка Kieferorthopedia (зав. каф., проф. M. Wehrbein) провели 11 науково-практичних семінарів.

Необхідною умовою покращення якості підготовки фахівців медичного спрямування є впровадження в навчальний процес засад доказової медицини та сучасних стандартів надання медичної допомоги. Тому особливу увагу академія приділяє забезпеченню навчання сучасними джерелами інформації. В академії нині працює бібліотека з потужним книжковим фондом, створені електронна бібліотека, академічний сайт, де розміщені навчально-методичні матеріали з усіх дисциплін. Натепер маємо досить велику кількість електронних посібників, які крім інформації, передбаченої навчальною програмою, містять багато додаткового матеріалу.

Висновок. Сучасне забезпечення якісної освіти лікарів-стоматологів зумовлене компетентнісним підходом до навчання і потребує від колективу академії безперервного вдосконалення, креативних ідей, реалізованих на надійній матеріально-технічній базі. Перехід до нових комп'ютерно-орієнтованих технологій навчання, створення умов для їх розробки, апробації та впровадження, раціональне поєднання з традиційними - вимога часу та складне педагогічне завдання, яке потребує розв'язання цілого комплексу психолого-педагогічних, організаційних, навчальнометодичних, технічних та інших проблем. 


\section{Література}

1. Вища освіта України і Болонський процес : [навч. посіб.] / за ред. В. Г. Кременя. - Тернопіль : Навч. книга-Богдан, 2004. -384 c.

2. Науменко У. Свропейський вектор розвитку: стратегія для України / У. Науменко // Вища освіта України. - 2008. №3. - С. 31-36.
3. Кліщ Г. І. Професійна компетентність як мета підготовки сучасних лікарів у медичних університетах Австрії / Г. І. Кліщ // Медична освіта. - 2011. - № 4. - С. 32-38.

4. Андрущенко В. Інформаційні технології в системі інноваційної освіти / В. Андрущенко, А. Олійник // Вища освіта України. -2008. - № 3.-С. 5- 15. 